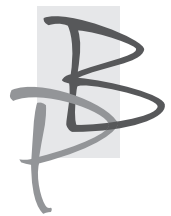

Helena Nielepko*

Grodzieński Państwowy Uniwersytet im. Janki Kupały, Białoruś https://orcid.org/0000-0002-4973-7594

\title{
Temat Wilna i Wileńszczyzny w Dziennikach Zofii Nałkowskiej
}

Streszczenie: Artykuł omawia Dzienniki Zofii Nałkowskiej z okresu wileńskiego. Region wileński, w którym sąsiadują narody litewski, polski, rosyjski i białoruski, jest miejscem współpracy między kulturami narodowymi. Nałkowska na początku nie czuła wartości płynącej z tego etnicznego zróżnicowania, bowiem po przybyciu do Wilna była przede wszystkim oczarowana pięknem natury tego kraju. Jednocześnie zaczęła uważniej przyglądać się życiu „małych ludzi”, obserwować wydarzenia polityczne i dostrzegać osobliwości polskiej polityki narodowej. Jej dziennik ujawnia zdolność do łączenia najbardziej intymnych uczuć i doświadczeń z refleksjami na temat wydarzeń politycznych, opisami miejskich pejzaży Wilna i uroczystości poświęconych Piłsudskiemu. Opisuje ona prostych ludzi, mieszkańców Wilna i okolic, ich przyjaciół. Omawia przebieg Kongresu Pisarzy Polskich w Wilnie.

Słowa-klucze: Nałkowska, memuarystyka, dziennik, Wilno, wielokulturowość

\footnotetext{
* Helena Nielepko - dr nauk hum., docent Katedry Języka Rosyjskiego jako Obcego w Grodzieńskim Państwowym Uniwersytecie im. Janki Kupały. Jest autorką monografii Драматургия Тадеуша Мициньского: проблематика и поэтика oraz licznych artykułów poświęconych twórczości dramatycznej T. Micińskiego.
} 


\section{Vilnius and Vilnius Region in Zofia Nałkowska's Diaries}

Summary: The article discusses the thematic scope of Diaries Zofia Nałkowska covering the period she spent in Vilnius. The Vilnius region, where the Lithuanian, Polish, Russian, and Belarusian nations coexist, is a place of cooperation between national cultures. Zofia Nalkowska did not feel that at the beginning, being enchanted by the natural beauty of the country. At the same time, she began to look more carefully at the lives of ordinary people, observe political events and saw the peculiarities of Poland's national policy. Her diary reveals Nalkowska's ability to combine the most intimate feelings and experiences with reflections on political events, the urban landscapes of Vilnius and the celebrations dedicated to Pilsudski. The writer describes simple people living in Vilnius and its neigbourhood. She also discusses of the General Congress of Polish Writers in Vilnius. The peculiarities of Nalkowska's perception of the world, the way in which her feelings, thoughts and observations were presented in Diaries this was also within the interest of the author of the article.

Key words: Nałkowska, memoirs, journal, Vilnius, multiculturalism

\section{Pranešimo pavadinimas: Vilnius ir Vilniaus kraštas Zofijos Nalkovskos (Zofia Nałkowska) dienoraštyje}

Santrauka: Rašytojo dienoraštis - tai savotiškas epo žanras, kuriame rašantis ji asmuo atlieka trigubą funkciją: autoriaus (pasirenka, jo požiūriu, svarbiausius ir esminius epochos ivykius), naratoriaus (tvarko medžiagą, kuria turini ir emocini pasakojimo bei herojaus charakteri. Iš vienos pusès, herojus yra panašus i naracinès prozos heroju, iš kitos - išreiškia savą santyki su konkrečiu istoriniu, ar dabarties ivykiu, aprašomu dienoraštyje.

Nalkovskos dienoraštis - tai savotiškas epinis romanas „apie laiką ir apie save“ (S. Jeseninas) ir yra vienas ilgiausių epochos aprašymų - apima beveik 50 metų laikotarpi. Todèl šio pranešimo užduotis ne analizuoti dienoraščio, apimančio tris Lenkijos ir pasaulio istorijos epochas, visumą, bet išnagrinèti nedideli Nalkovskos gyvenimo bei lenku literatūros istorijos fragmentą, susijusi su vienu autorès apsilankymu Vilniuje ir Vilniaus krašte. 
1922 m. ji ištekèjo už I pasaulinio karo ir Lenkijos išlaisvinimo judejjimo didvyrio, kuris gavo nukreipimą i šalies rytinius paribius. Nalkovskos gyvenime ivyko du esminiai pokyčiai: iš sostinès - Varšuvos „damos“ ji tampa karininko žmona. Viena vertus, santuoka buvo sudaryta iš didelès meilès, tačiau ta meilè nebuvo „gera“, kadangi abu buvo pernelyg skirtingi: ji - kūrybingos prigimties, žinomų kūrinių autorè, jis - Pilsudskio talkininkas, šventai vykdantis isakymus ir karines funkcijas, privačiame gyvenime - medžioklių mégèjas. Tad Nalkovska matè Vilnių per literatūrinio ivykio - Adomo Mickevičiaus jubiliejaus prizmę, o jis - kaip provincijos miestą, kuriame tarnavo.

Raktiniai žodžiai: R Nałkowska, prisiminimai, dienoraštis, Vilnius, daugiakultūriškumas.

Wiek XX odszedł w przeszłość, ale nie stał się jeszcze historią. Postawił przed każdym człowiekiem i całą ludzkością pytania globalne, zmusił do refleksji nad światem jako dziedzictwem pozostawionym potomnym, zwłaszcza w aspekcie dwóch sprzecznych tendencji: globalizacji i dążenia do zachowania tradycji. Szczególnego znaczenia nabiera w czasach współczesnych śledzenie w nauce i kulturze każdego narodu tych trendów, które łączą je z innymi. Między narodowymi i ogólnoludzkimi wartościami istnieją organiczne związki. W ich zrozumieniu pomagają typologia i porównanie. Pozwalają poprzez czynniki narodowe zobaczyć ogólnoludzkie przejawy w kulturze współczesnej. Znany rosyjski literaturoznawca Wiktor A. Choriew przekonywał:

Dziś filolog, który bada relacje literackie, coraz bardziej staje się historykiem kultury. Literackie fakty, w tym „związki literackie”, stara się traktować jako części ogólnego procesu kulturowego, rozpatrywać je w kontekście zjawisk danej kultury narodowej jako całości ${ }^{1}$.

1 В. Хорев, Имагология и изучение русско-польских литературных связей, [w:] Поляки и русские в газах друг друга, Москва 2000, s. 22. 
Znamienny przykład materiał w tym zakresie dają takie regiony jak Wilno, Grodno, Lwów, których kultura wyróżnia się niesamowitą oryginalnością i ma wielowiekowe tradycje. W latach 20.-30. XX wieku tereny te w Polsce nazywano ,ziemiami kresowymi”, gdyż były to wówczas obrzeża państwa polskiego. Narodowy skład tych ziem był bardzo różnorodny. Każdy z regionów stawał się swoistym centrum wielonarodowej kultury i miejscem mieszania się języków, zwyczajów i etnograficznych osobliwości mieszkających tu narodowości. Potwierdza to historyczno-literackie dziedzictwo Wilna i Wileńszczyzny, ukształtowane w latach międzywojennych.

O współdziałaniu kultur, które, jak pokazuje doświadczenie estetyczne ludzkości, prowadzi nie ku upodobnieniu, ścieraniu się różnorodności kultur narodowych, lecz ku wzbogaceniu ogólnoludzkiej kultury nowymi osiągnięciami - pisze białoruska polonistka Swietłana F. Musijenko². Zaznacza, że doskonale rozumieli to intelektualiści XX wieku, a w szczególności ci jej przedstawiciele, którym przyszło żyć i tworzyć w miejscach wielokulturowych, i to nie tylko w Wilnie lub Grodnie, ale i w takich dużych miastach jak Paryż, Moskwa, Nowy Jork. Dla nich charakterystyczna jest wielojęzyczność i wielokulturowość, przy występowaniu jednego z języków jako języka państwowego, który zajmuje miejsce też języka komunikacji międzynarodowej.

Niezwykłość sytuacji społeczno-historycznej i przygraniczne usytuowanie tych ziem, bliskie sąsiedztwo narodu litewskiego z narodami polskim, rosyjskim, białoruskim, ich wzajemna interferencja uczyniły Wileńszczyznę miejscem, gdzie w sposób osobliwy wchodziły w interakcje kultura i sztuka sąsiadujących narodów i wyraźna stała się tendencja do ich zbliżenia. Opierała się ona na wspólnocie historycznych i społecznych losów tych narodów, podobieństwie ich ideałów, bliskości tradycji folkloru i kultury. Ale w tym samym czasie każdy z mieszkających na Wileńszczyźnie narodów starał się zachować swoje cechy etniczne, a przede wszystkim język, zwyczaje, kulturę. Obie tendencje obecne są do dziś.

2 С. Ф. Мусиенко, Тема Вильно и Виленщины в дневниках Зофьи Налковской и Максима Танка, [w:] Славянскія літаратуры у кантэксие сусветнай. Матэрыяльь V Міжнароднай навуковай канферэнщы пі, прысвечанай 80-годдзю Беларускага дзяржайнага універсітэта у трох частках, Частка 2, Мінск, БДУ, 2001, с. 220-233. 
Kiedy w lipcu 1922 roku znana polska pisarka Zofia Nałkowska przyjechała na Wileńszczyznę, do małej wsi Zameczek, zaznaczyła w dzienniku swoje pierwsze wrażenia:

Czasami wyjeżdżam końmi na spacery - i widzę "te pagórki leśne”, "te łąki zielone, szeroko nad błękitnym Niemnem rozciągnione”, „te pola malowane zbożem rozmaitem"... Uczuwam naturę tutejszą wciąż w formułach gotowych z Pana Tadeusza. Chodząc po lesie za grzybami, słysząc o polowaniach - wciąż sprawdzam trafność wizji, wytworzonej niegdyś tą lekturą dzieciństwa (Zameczek pod Wilnem, 9 IX 1922) 3 .

W tej fascynacji opisami Mickiewiczowskimi Nałkowska nie zastanawia się nad tym, co być może nas, współczesnych badaczy i czytelników, nurtuje. Jakie tereny nadniemeńskie opisywał swym słynnym „Litwo! Ojczyzno moja!"4, rozpoczynającym Pana Tadeusza, polski poeta, urodzony na Nowogródczyźnie, a nazywający siebie Litwinem? Nałkowska zauroczona jest pięknem kraju i w dalszych partiach dziennika już mówi o tym własnymi słowy:

Stoimy nad stawem, wygrodzonym przez młyn z rzeczki, żywiącej swą wąską, wesołą wodą olbrzymy drzewne, wierzby potwornych rozmiarów i kształtów; księżyc wysrebrza płaską wodę, nenufary i trzciny. Drzewa brzegów, straszliwe i piękne, srebrne, puszyste, jak widma i symbole ${ }^{5}$, [...]. Najpiękniejsze są role już zaorane, wykładające zbocza pagórków, jak dywany różnych barw brązowych i fioletowych ${ }^{6}$.

Widać, że najbardziej zachwycają pisarkę te obrazy natury, które obejmują cały horyzont, pozwalają sięgnąć okiem daleko w przestrzeń:

Z jednej krawędzi ukazał się widok najpiękniejszy, jaki tutaj widziałam. Wielka dolina, zasłana bliżej wierzchami złotymi lasu z piramidalną, ciemną zielenią

3 Z. Nałkowska, Dzienniki 1918-1929, Warszawa 1980, s. 85.

4 A. Mickiewicz, Pan Tadeusz, Warszawa 1963, s. 7.

5 Z. Nałkowska, Dzienniki, dz. cyt., s. 85-86.

6 Tamże, s. 89. 
świerków, rozwijającą się w niezgłębione dale, stoki, gaje, smugi lasów, dalekie krainy zieleni, złota, łąk, pól, malutkich już wreszcie, jak obrazki.

Krajobrazy takie dają pisarce poczucie wolności, a ich opisy są niezwykle emocjonalne i przypominają poemat prozą:

Uroczy jest ten kraj - pewna wioska Sałata nad małym jeziorem, gdzie indziej znów Smolnica, ukryta po dachy w dolinie; wszędzie te stoki, zbocza, za siebie ku dolinie zachodzące, smugi lasów, rzeczki w zielonych korytarzach, szachownice pól...8.

Wydaje się, że pisał te partie dziennika ktoś inny, a nie pisarka posiadająca i doświadczenie polityczne, i sławę europejską. Obok podobnych opisów przyrody, dłuższych partii lirycznych, możemy tu spotkać zupełnie inne notatki w stylu rzeczowych obserwacji czy relacji, na przykład: „Krowy piły wodę, owce nie". Jednak dalej na kartkach Dziennika kilka razy wraca obraz owiec i już dokładniej pisze Nałkowska o swojej fascynacji nimi, o tym, że wydają jej się czasem „przerażające”, „pół ludzkie, pół potworne” i „dziwne”. Przez takie uwagi mamy możliwość „zajrzenia” w głąb psychiki autorki Dziennika.

Tym bardziej, że głębokie odczucie piękna świata i przyrody łączy się w dzienniku z czymś zupełnie innym: beznadzieją, ciężkim cierpieniem i zatroskaniem o świat, o ludzi, o Polskę.

$\mathrm{Na}$ Wileńszczyźnie lata 20. i 30. były okresem bardzo trudnym. Życie i kultura tej ziemi stały się kolebką polityczną odradzającej się Polski. O przejawach społeczno-historycznych, kulturze i losach ludzi w tym okresie świadczą różne źródła. Miara obiektywizmu refleksji na tematy wileńskie zależy od dokumentalnej ścisłości samych źródeł i postaw obywatelskich ich autorów i twórców. Niektóre aspekty życia Wilna i Wileńszczyzny znalazły odbicie też w dziennikach lat 20. XX wieku Zofii Nałkowskiej. Pobyt na Wileńszczyźnie pozostawił głęboki ślad w jej twórczości, przyczynił się do jej demokratyzacji i ukształtowania filozoficznej wizji rzeczywistości.

7 Tamże, s. 92.

8 Tamże, s. 85 .

9 Tamże, s. 89. 
Nałkowska na ziemiach „dalekiej północy”10 zaczęła uważniej przyglądać się życiu „małych ludzi”, obserwować wydarzenia polityczne i dostrzegać osobliwości polityki narodowościowej Polski. Jej dzienniki to szerokie płótna epickie ze szczegółowymi opisami własnego życia, zdarzeń, charakterów ludzi, natury, nawet zwyczajów zwierząt. Widać tu współczucie dla człowieka i troskę o jego przyszłość. Dlatego dzienniki Nałkowskiej lat 20. i 30. XX wieku postrzegane są przez współczesnego czytelnika nie tylko jako historii, ale jako dzieło artystyczne, z których kartek przemawiają wielkie i tragiczne wydarzenia z przeszłości.

Posiadając dużą siłę oddziaływania, dziennik, jak żaden inny gatunek literacki, pomaga zrozumieć i właściwie ocenić rzeczywistość i historyczne doświadczenia pokoleń. Łączy on w sobie elementy faktograficzne i emocjonalną wiarygodność, gdyż wydarzenia w nim opisane autor-narrator przeżył bezpośrednio, a zatem zostały ,przepuszczone” przez jego umysł i serce. Tego rodzaju filtr emocjonalny daje najpełniejszy efekt, gdyż czytelnik również reaguje emocjonalnie, wyraża swój stosunek i do wydarzenia, i do autora, i do cech prezentacji materiału. Synteza racjonalnego i emocjonalnego czynnika w dziele przyczynia się do wzmocnienia świadomości człowieka, zmusza go do porównywania lub kojarzenia opisanych wydarzeń z własnymi wyobrażeniami o życiu, o obywatelskim obowiązku, o ludzkim powołaniu. Dziennik pomaga nie tylko w poznaniu epoki, ale daje też możliwość zobaczenia autora, prześledzenia jego ewolucji na tle „prawdziwego” życia, otwierając współczesnemu człowiekowi duchową atmosferę innej epoki, zachowując historyczną wiarygodność materiału dokumentalnego.

Nałkowska nazwała memuarystykę „motylem zatrzymanym w locie”. Jednak jeśli chodzi o dziennik lub pamiętnik działacza kultury, jego funkcje się rozszerzają: jest i „ludzkim dokumentem” (Nałkowska), i faktem kultury narodowej, i swoistym dziełem artystycznym (powieścią ich-formy), w którym autor opowiada „o czasie i o sobie” (S. Jesienin). Tak naprawdę dziennik twórcy, działacza kultury przy absolutnej swobodzie formy jest pełnoprawnym utworem artystycznym i jednocześnie też faktem tej kultury, którą reprezen-

10 Tamże, s. 85. W ten sposób sama Z. Nałkowska w pierwszej notatce w Zameczku (9 września 1922 r.) określiła miejsce, do którego przyjechała z Warszawy za mężem J. Gorzechowskim. 
tuje autor. Dlatego krzyżują się w nim role autora, człowieka występującego równocześnie $\mathrm{w}$ roli narratora $\mathrm{i}$ bohatera.

W dzienniku ważne zadanie pełniąą trzy czynniki: dokumentalny, filozoficzny i emocjonalny. Jak literatura faktu, ma on możliwość swobodnego przedstawiania zdarzeń i nie jest skrępowany obowiązującymi zasadami przyjętymi w innych gatunkach prozaicznych. Charakter narracji zależy w nim od materiału i stosunku autora do tego, co się dzieje. Znaczącą rolę odgrywa czynnik psychologiczny, za którego pomocą pisarz nadaje analizowanym wydarzeniom ekspresję. W dziełach memuarystyki najpełniej odzwierciedlają się tradycje gatunkowe eseju, który zakłada swobodną interpretację problemu, swobodne operowanie wydarzeniami i indywidualne autorskie nastawienie do nich. Dziennik jest jednocześnie dokumentalnym świadectwem epoki i samodzielnym gatunkiem, w którym autor występuje w roli historycznego świadka epoki i w roli bohatera dzieła.

Wpisy dziennikowe Nałkowskiej budowane są zazwyczaj według schematu: od faktu ku jego ocenie czy refleksji nad nim, a następnie przekazywane jest emocjonalne postrzeganie tego, co dzieje się z pisarzem. Pozwalają na zobaczenie autora w ciągu jego życia, w rozwoju całej epoki, którą był ważny odcinek historii położony pomiędzy dwiema tragicznymi datami - pierwszą i drugą wojnami światowymi.

Wileński okres w dziennikach Nałkowskiej zajmuje mało miejsca. Etap życia pisarki związany ze wschodnim pograniczem Polski (1922-1927) zaczyna się i kończy na Wileńszczyźnie. Kilka miesięcy życia w Zameczku pod Wilnem, położonym w malowniczym lesie nad brzegiem jeziora, stało się preludium grodzieńskiej epopei, która wywróciła znany pisarce świat. Wówczas zmieniła hałaśliwą Warszawę na cicha wioskę, literackie salony stolicy odeszły w przeszłość, a na pierwsze miejsce wysunęła się nowa rzeczywistość - prowincja z jej zastygłym, szarym światem. Mąż pisarki - dowódca żandarmerii polowej, najpierw w Wilnie, a następnie w Grodnie - wypełnił jej życie zakazami i ograniczył krąg znajomych i przyjaciół, z niechęcią przyjmował twórczość żony. W Wilnie i Zameczku pisarka starała się być „zwykłą oficerską żoną”:

Mąż każdego dnia przybywa na obiad z Wilna, a ja czekam. [...] Znam tu tylko oficerów i oficerskie żony. Sama też jestem tylko żoną oficera ${ }^{11}$.

11 Tamże, s. 86. 
Po przeczytaniu kilku podobnych wypowiedzi pojawia się wrażenie, że autorka dziennika próbuje siebie o tym przekonać. W losach pisarki możemy zaobserwować pewien paralelizm: pierwsze jej podróże do Wilna i do Grodna związane są z ,niedobrą miłością” do męża - pułkownika żandarmerii Jana Jura-Gorzewskiego. Dlatego w dzienniku pisarka wiele uwagi poświęca refleksji o swoim nieszczęśliwym losie. Dość często w okresie lat 1922-1923 wpisy w dzienniku zawierają słowa: „Jan zmusił mnie...”. Jedynym pocieszeniem dla Nałkowskiej była wtedy twórczość.

Właśnie w tym okresie kończy pisarka pracę nad swoją pierwszą powieścią polityczną, która otworzy nowy rozdział w polskiej literaturze - Romans Teresy Hennert. W niej po raz pierwszy podjęte zostały problemy odradzającego się kraju. Pod wpływem obserwacji życia na pograniczu dopisywała Nałkowska nowe epizody. Walka o władzę między różnymi partiami politycznymi, podczas której wiele przywódców zapomniało o losach ojczyzny, wykorzystywanie religii jako propagandy, znieważanie praw narodów zamieszkujących obrzeża Polski - wszystkie te zjawiska nie tylko znalazły odzwierciedlenie w powieści, ale zostały również przeplecione losami głównej pary bohaterów - kochanków Teresy Hennert i pułkownika Omskiego. Ona sprzedała swoją duszę za pieniądze, on się podporządkował wojnie. Sadyzm Omskiego był nie tylko wynikiem wrodzonych cech, ale kształtował się pod wpływem norm moralnych epoki. W tym kontekście interesujący jest epizod, w którym autorka analizuje instynkt wojny czający się w duszy „człowieka militarnego”, którym bez wątpienia był Omski, wzorowany na osobie Jana Jura-Gorzechowskiego. Okrucieństwo pułkownika podsycało się życiem: marzył o wojnie i w oczekiwaniu na nią ,zastygł jak pies gotowy do skoku na swoją ofiarę”. Ukazując człowieka „,nowej koniunktury”, dążącego do przejęcia władzy, pisarka nie tylko wyrażała swój niepokój, ale zapraszała czytelnika do zastanowienia się nad własnym życiem.

Dziennik pozwolił objawić się niesamowitej umiejętności Nałkowskiej, jaką było łączenie najbardziej intymnych uczuć i doświadczeń wewnętrznych z refleksjami na temat wydarzeń politycznych, opisami miejskich krajobrazów Wilna i uroczystości poświęconych Piłsudskiemu. Dlatego właśnie ujawniają się i krzyżują w dziennikach różne stylistyki i sposoby pisania, najczęściej liryczny i publicystyczny. Dziennik Nałkowskiej jest swoistą ich-powieścia, utworem jednego bohatera na bogatym tle burzliwej epoki. Nałkowska pisała go z pozycji obywatela odradzającego się kraju. Pisarka 
doskonale widziała wady, krytykowała kurs polityczny, piętnowała społeczną niesprawiedliwość, broniła prawa więźniów politycznych i mniejszości narodowych. Ale w tym samym czasie zdawała sobie sprawę, że odrodzenie Polski jest znaczącym wydarzeniem historycznym. Zwracała uwagę na zaostrzenie politycznych i narodowych sprzeczności i wykazywała niepokój o losy kraju i świata. Dzienniki Nałkowskiej są bogate w wydarzenia epoki, dużo jest opisów wyborów do Sejmu i Senatu w listopadzie 1922 roku. Pisze Nałkowska o swoich nieudanych próbach zjednania głosów na listy lewicowe, o nadziejach na to, że ludzie, którzy nawet w deszcz przyszli do lokalu wyborczego, zagłosują na listy ludowe, na człowieka, który rzeczywiście, jej zdaniem, będzie działał w interesie ludu. Nałkowska opisuje swoje nadzieje, umiejętnie podnosząc napięcie po to, by rzucić potem siebie (lub domniemanego czytelnika) „na ziemię":

I wreszcie nastaje gnuśna, ale istotna prawda niemiłego odkrycia rzeczy wiadomej: głosuje oto ciemny, głupi łłum, waży szale losów w zależności od tego, kto pierwiej przeniknął w te chałupy agitacją, kto głośniej krzyczał, lepiej zachwalił, kto drożej był zapłacony ${ }^{12}$.

Pierwsze wybory na tych ziemiach w niepodległej Polsce przyniosły grę w demokrację. Smutne refleksje pisarki długo pozostawały aktualne i nie gubiły swojego moralno-politycznego znaczenia.

Straszny ślepy nonsens całej niebezpiecznej lub raczej błahej loterii, zakołysanie się ciężkiej wielkiej masy biologicznej. Rozwiewa się złudzenie, że coś z tego wszystkiego jest lepsze, a coś gorsze, że coś w ogóle jest ważne - dlatego, że o niektóre sprawy toczą się walki albo bójki, że los ludzi albo gromad jest w grze. We Włoszech zwyciężyli faszyści, w Anglii konserwatyści, jakieś śmiertelne, ostatnie nadzieje może się rozpadają i walą ${ }^{13}$.

Podczas pobytu Zofii Nałkowskiej w Zameczku na karty jej dziennika trafiają opisy prostych ludzi, są to między innymi: „litewscy chłopi z kobietami” przy

12 Tamże, s. 95.

13 Tamże. 
lokalu wyborczym, stary pastuch owiec oraz służąca Nałkowskiej. Tej ostatniej poświęca pisarka więcej uwagi, nazywając ją „półdziką Litwinką” - „godną, by być zapisaną - ale trudną, nieomal symboliczną, tak fizyczną i pierwotną"14. Z krótkiej uwagi można zrozumieć, że Nałkowska pomaga jej w pisaniu listu miłosnego i że bardzo ją zainteresowała ta pełna życia prosta kobieta.

Nie mogło w dzienniku zabraknąć Wilna i jego mieszkańców. Wspomina o znajomych ze służby męża, o zwiedzaniu miasta, przy okazji znowu przywołując Mickiewicza. Tak opisuje swoje wrażenia:

Wilno jest pięknym miastem, daje masę wzruszeń i zachwytów. Szkoda, że muszę go opuścić. Na raucie, wydanym niedawno z okazji przyjazdu Piłsudskiego, widziałam wiele osób znajomych i wybitnych, czułam się zupełnie nie jak na zesłaniu ${ }^{15}$.

Niewątpliwie warszawianka, która przywykła do gwarnego i ciągle tętniącego życiem stołecznego miasta, gdzie takie wydarzenia, jak raut na cześć ważnej osoby, są codziennością, mogła tak się poczuć na tej „dalekiej północy”. Opisując uroczystość, podkreśla jej zewnętrzne cechy, takie jak powaga i średniowieczna dekoracyjność, które się jej spodobały. Wymieniając dalej nazwiska profesorów precyzuje, że są oni jej starymi znajomymi. $Z$ wileńską inteligencją Zofia Nałkowska utrzymywała dość mocne więzi. Znajduje to odzwierciedlenie w dziennikach, gdy czytamy o jej późniejszym przyjeździe do Wilna w 1929 roku. Wtedy wychodzą na powierzchnię jej przyjaźnie i znajomości, krótkie spotkania, wizyty i rozmowy trafiają na karty dziennika w tym samym stopniu, co wydarzenia codzienne, a długim relacjom czy opisom daje Nałkowska miejsce w listach ${ }^{16}$. Teraz zaś, w 1922, pisze:

...Największym zdarzeniem mego tutejszego życia były krótkie odwiedziny matki. Ta moja najdroższa była tutaj... żywa, młoda i taka kochająca. ...Wszystko jest mi bliższe po jej wizycie ${ }^{17}$.

14 Tamże.

15 Tamże.

16 Można to zauważyć dzięki obszernym komentarzom Hanny Kirchner, w których cytuje ona listy Nałkowskiej do przyjaciół i znajomych z dłuższymi wypowiedziami o sytuacjach wspomnianych w Dzienniku (np. list do Zofii Villaume-Zahrtowej, tamże, s. 95).

17 Tamże, s. 96. 
W Dzienniku, a dokładniej we fragmencie, który pisała, mieszkając w Zameczku pod Wilnem, Nałkowska koncentruje się przede wszystkim na opisach piękna przyrody, własnych przeżyć. Zarysowyje też sceny polowań, które uwielbiał jej mąż. Później w dzienniku pojawi się obraz prześladowanego zająca, do którego będzie porównywała Nałkowska siebie. Wileńskie partie pamiętnika są smutnym preludium do nieszczęśliwego życia rodzinnego pisarki (aspekt psychologiczny) i jej społeczno-politycznej działalności w Grodnie, związanej ze służbą w „Patronacie” (aspekt społeczny). Dekada życia „pod znakiem Jura” (Gorzechowskiego) i „razem z nim” skończyła się rozpadem rodziny i odejściem Nałkowskiej od męża.

Druga wizyta w Wilnie, jak i ostatni pobyt w Grodnie, był dla Nałkowskiej podsumowaniem smutnych wyników jej feralnego małżeństwa, ale też początkiem nowego etapu życia. Do Wilna (1928), Grodna (1929) i Nowogródka (1931) przyjechała już jako delegat PEN-klubu i członek Zarządu Związku Pisarzy Polskich. Symptomatyczne, że w zapisach wrażeń o tych trzech wyjazdach powtarza się prawie jedna i ta sama myśl: pisarkę cieszy zainteresowanie, jakie wywołuje wśród ludzi, cieszy odzyskana wolność i kontakty z przyjaciółmi, cieszy piękno przyrody i popularność na ziemiach nadniemeńskich, jaką wzbudza twórczość Adama Mickiewicza i Elizy Orzeszkowej.

Nałkowska została wybrana delegatem Powszechnego Zjazdu Literatów Polskich, który odbywał się w Wilnie w dniach 1-4 listopada 1928 roku. Pisarka wskazywała na osobliwość intelektualnej atmosfery zjazdu, który wypracował „bardzo surową rezolucję pod adresem rządu”, a pisarze różnych kierunków ideowych wyrazili ogólne niezadowolenie z postawy władz, również wobec spraw kultury. Wiele uwagi na zjeździe poświęcono twórczości Adama Mickiewicza. Nałkowska omawia przemówienie prezesa wileńskiego oddziału związku pisarzy Mariana Zdziechowskiego, nazywając je „w najwyższym stopniu wileńskim”. Na zjazd wpłynęły estetyczne i ideowe spory polskich działaczy kultury w ocenach romantyzmu i twórczości Mickiewicza. Miasto zachowało świętość pamięci o wielkim poecie. Inteligencja i młodzież studencka wspierali swoisty kult Mickiewicza. W związku z tym Nałkowska pisała o niedorzecznej sytuacji, w której się znaleźli przeciwnicy romantycznych tradycji w literaturze Karol Irzykowski i Jan Nepomucen Miller, przekonani, że kult Mickiewicza i całej literatury romantycznej - to tylko „Zwykłe sentymenty". Ale zjazd nie poparł tego punktu widzenia i dlatego, zdaniem pisarki: 
Miller wiele doznać musiał utrapienia w atmosferze tego zjazdu, gdzie w każdym z uroczystych przemówień słyszało się o tym Mickiewiczu, o Wilnie, kolebce geniusza, o miłości i nawet mesjanizmie... Ten Miller z Irzykowskim wyglądali jak dwa diabły kropione święconą wodą ${ }^{18}$.

Wyniki pracy zjazdu i analiza dyskusji o romantyzmie i realizmie w literaturze polskiej w dzienniku Nałkowskiej przedstawione są z niezwykłą wyrazistością. I pomimo tego, że uważano ją za „najlepszą uczennicę realistycznej szkoły Stefana Żeromskiego"19, pisarka była wielbicielką twórczości Adama Mickiewicza i widziała Wileńszczyznę wyłącznie przez pryzmat dzieł tego wielkiego romantyka.

Wileński zjazd nie zaprzeczył ani rozwojowi literatury realistycznej, ani jej nowej koncepcji świata i człowieka. Jednak uczestnicy zjazdu podkreślali szczególne znaczenie romantycznych tradycji w polskiej literaturze XX wieku i ważną w nich rolę Adama Mickiewicza. Miller w znanym dziele Zaraza $w$ Grenadzie i Irzykowski w cyklu prac literaturoznawczych w zbiorze Czyn i słowo przeciwstawiali tradycji romantycznej realizm, podkreślając jego ważną rolę zwłaszcza w literaturze lat 20. XX wieku.

Znaczenie zjazdu, zdaniem Nałkowskiej, polegało na jego demokratycznej orientacji, która wyrażała się dosłownie w każdym przemówieniu jego delegatów (Zdziechowskiego, Pigonia, Radziwiłowicza, Osterwy) oraz rezolucjach, które osądzały dyktaturę rządu w dziedzinie literatury. Nałkowska odnotowuje też entuzjazm duchowy, który panował w mieście podczas trwania zjazdu:

Atmostera tego uniwersyteckiego miasta, pełnego teraz ideowych, entuzjastycznych ludzi, jest niezwykła i pociągająca ${ }^{20}$.

Wyjazd do Wilna był ważny dla Nałkowskiej również z tego względu, że poddała ponownej ocenie własne życie i w dzienniku po powrocie z Wilna do Warszawy zapisała (pod datą: 5.11.1928 roku):

18 Tamże, s. 376.

19 K. Irzykowski, Cięższy i lżejszy kaliber, Warszawa 1957, s. 177.

20 Z. Nałkowska, dz. cyt., s. 376. 
Miasto widziane przed sześciu laty w kategoriach wędrówek wojskowych - tym razem było dla mnie terenem ciekawych poznań i spotkań21.

Było to ważne spotkanie z własną nieszczęśliwą przeszłością. O niej przypominali tylko koledzy jej byłego męża, którzy przyjechali „specjalnie”, aby „zobaczyć” pisarkę. O nich wspomina Nałkowska z goryczą. Ale były też spotkania z ludźmi bliskimi duchem, o podobnych poglądach. Z nimi łączyła twórczynię dawna przyjaźń i wspólne ideały. W Dzienniku wspomina imię zmarłego rewolucjonisty z 1905 roku Ludwika Licińskiego i opisuje rozmowy z uczestnikami rewolucji Radziwiłowiczem i Pogorzelskim.

Dwie wycieczki Nałkowskiej na Wileńszczyznę i do Wilna są swoistym obramowaniem, w którym zawarła w dzienniku opis pierwszej dekady istnienia niepodległej Polski, polityki i życia wielu państw europejskich, trudnych problemów pojawiających się na ziemiach pogranicza, ważnych wydarzeń w literaturze, teatrze, środowisku pisarskim. I na tle niezwykłej różnorodności epoki - los autora, narratora i bohatera dziennika, pisarki-humanistki Zofii Nałkowskiej.

Dzienniki Nałkowskiej charakteryzują się wysokim poziomem artystycznym, świadczącym o talencie autorki. W związku z tym można z pełnym uzasadnieniem mówić o narodzinach nie tylko w jej twórczości, ale i w literaturze okresu międzywojennego nowej odmiany gatunku: powieści-dziennika, łączącego cechy literatury faktu, eseju i prozy.

\section{Bibliografia}

Choriew W. A., Imagołogija i izuczenije russko-polskich litieraturnych swiaziej, [w:] Polaki i russkije w glazach drug druga, Moskwa 2000.

Irzykowski K., Cięższy i lżejszy kaliber, Warszawa 1957.

Mickiewicz A., Pan Tadeusz, Warszawa 1963.

Musijenko S. F., Tiema Wilno i Wilenszcziny w dniewnikach Zofji Nałkowskoj i Maksima Tanka, [w:] Sławianskija litaratury y̆ kantekscie suswietnaj. Materyjały V Miżnarodnaj nawukowaj kanfierencyi, pryswieczanaj 80-goddziu Biełaruskaga dziarżay̆naga uniwiersiteta u troch czastkach, Czastka 2, Minsk 2001.

Nałkowska Z., Dzienniki 1918-1929, Warszawa 1980.

21 Tamże, s. 375. 